\title{
Néma TV, néma tavasz?
}

(Hozzászólás a média és az ökológia válság kapcsolatát - Sükösd Milós írása nyomán - feszegető vitához)

\section{Szerzői információ:}

Fonyó Attila

Szociológus, újságíró. Az ELTE végzett doktorandusza, disszertációját környezetvédelemi szabályozásban fellépõ aktorok közötti kommunikációból írja. Óraadó oktató az ELTE szociológia szakán.

Főbb kutatási területei: környezetvédelmi kommunikáció, társadalmi mozgalmak, civil társadalom, társadalmi struktúra, rendszerváltás. Szociológusi tevékenysége mellett szabadúszó újságíróként dolgozik - környezetvédelemmel, civil társadalommal kapcsolatos cikkeket publikálva. 2001-2004. között a Tilos Rádió ökológiai magazinjának músorvezetốje volt.

E-mail: fonyikuld@yahoo.co.uk

Így hivatkozzon erre a cikkre:

Fonyó Attila. „Néma TV, néma tavasz?”.

Információs Társadalom IV, 3-4. szám (2004): 108-128.

https://dx.doi.org/10.22503/inftars.IV.2004.3-4.15

A folyóiratban közölt müvek

a Creative Commons Nevezd meg! - Ne add el! - Így add tovább! 4.0

Nemzetközi Licenc feltételeinek megfelelöen használhatók. 
Fonyó Attila

Néma TV, Néma tavasz?

Hozzászólás a média és az ökológiai válság kapcsolatát -

Sükösd Miklós írása nyomán - feszegetô vitához

\section{„DDT is good for me-e-e!” \\ Tehenekkel illusstrált reklám a TIME magazinból, 1947}

„A svéd férfi 24 hektárnyi földet kezelt DDT-t és benzén-hexaklórt tartalmazó porral, mely az enyhe szellőben mindvégig ott kavargott körülötte. „Este szokatlan fáradtságot érzett, a következő napokon pedig általános gyengeség, hidegrázás, hátés lábfájás kínozta, s nem tudott felkelni az ágyból « - szólt a lundi kórház beszámolója. Magas láz gyötörte, s vörösvérsejtjeinek száma igen alacsonyra zuhant- Átvitték egy felkészültebb kórházba, de ott sem tudtak rajta segíteni, és tíz hét után meghalt. A vizsgálat a csontvelő teljes elroncsolódását mutatta ki."

Rachel Carson „Néma tavasz” címü, az 1967 és 1973 között a fejlett nyugati és a szocialista országokban betiltott DDT-ról és más rovarirtó szerekról írt könyvébôl, 1962

„[...] Habár a DDT-t már 30 évvel ezelőtt betiltották, Margot Wallströmnek, az Európai Környezetvédelmi Bizottság vezetôjének vérében még mindig kimutatható..."

Az európai döntéshozók vérvizsgálatát megcélzó civil akcióról szóló beszámolóból, mely a kémiai anyagok szabályozásának szükségességére hívja fel a figyelmet, www.wref.hu, 2003

Sükösd Miklósnak az ökocídium (környezeti válság) és a totális mediatizáció (a nyugati társadalmak növekvő médiafogyasztása) közötti kapcsolatot feszegetô téziseit és az azt bírálók kritikáját olvasva a hozzászólónak olyan érzése támad, hogy Sükösd Miklós kritikusai nem látják a fától az erdőt, míg a vitaindító ott is savas esốtôl lombját hullató erdőt lát, ahol valójában végtelen legelők világosodnak. Azaz a kritikusok sokszor részproblémák cáfolatával kerülgetik az alapkérdéseket, míg Sükösd valóban nem elég árnyaltan, túlságosan fekete-fehéren adja elố téziseit, néha összemosva vagy nem elég pontosan tálalva állításokat, fogalmakat.

\section{A KÖRNYEZETI KÉRDÉS}

Az első és legfeltűnőbb a vitában a környezeti kérdésnek, magának a környezeti válságnak a viszonylag felszínes vagy elhanyagolt kezelése, néhány hozzászólónál teljes negligálása. Már maga Sükösd is elköveti azt a hibát, hogy a kétségtelenül hatásos ökocídium fogalmat emeli ki, azaz a fajok pusztulását, eltűnését, a biológiai sok-

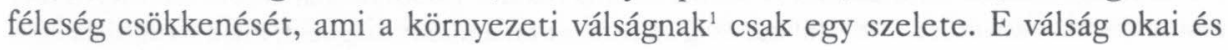
megoldási lehetôségei azonban sokrétû́ek, s így a médiával való összefüggéseik is feltehetôleg mások.

\footnotetext{
'A továbbiakban a környezeti válság fogalmát használom az ökológiai válság helyett, ugyanis az ökológia egy diszciplína, nem pedig egy diszciplína tárgyának a neve.
} 
Élő és élettelen környezetünk terhelése eleve kettôs: a környezetet egyrészt erőforrásként (input), másrészt nyelőként, azaz a gazdasági-társadalmi rendszer által termelt hulladékok lerakóhelyeként (output) használja az emberiség. E használat lehet tartós kisléptékủ erőforrás-használat, ami az erőforrások kimerülését okozhatja, vagy tartós kisléptékû környezetszennyezés, ami hosszú távon ökológiai problémákat okoz. De a környezetszennyezés lehet hirtelen katasztrófa is, melynek során súlyosan megrendülhet egy természeti rendszer egyensúlya. E dimenziók mellett nyilvánvalóan fontos megkülönböztetni az adott gyakorlatok erőforrás-kihasználásának, illetve környezetszennyezésének közvetett vagy közvetlen jellegét. A környezeti konfliktusok leggyakoribb oka a NIMBY (not in my backyard), a „ne az én kertembe” típusú tiltakozás, azaz egy környezetszennyező vagy annak vélt beruházás megakadályozása a tiltakozók közvetlen környezetében.

A létezố környezetterhelố gyakorlatok mellett másfajta környezeti problémát jelentenek a környezeti kockázatok. Egy gazdasági-technológiai rendszer vagy gyakorlat rövid vagy hosszú távú, nem szándékolt környezeti és egészségügyi hatásairól rendszerint nem sokat tudunk: csak becslések vannak ezek mértékéről és bekövetkezési valószínúségérôl. Ráadásul a környezetszennyezés egy részének nincs sok köze a természetromboláshoz. Az épületek belső levegőminősége vagy a városi zajártalom nem rongálja a bioszférát, csak az elóbbi nem megfelelő volta megsokszorozza a légúti megbetegedések számát, az utóbbi pedig 5-10 évvel megrövidíti az emberi életet. Sőt, sokszor a laikusok által környezeti katasztrófának tekintett jelenségek egy része nem is az, hanem az adott ökoszisztéma múködésének része (erdőtüzek az eukaliptuszerdôben, elefántok erdôpusztítása, üregi nyulak randalírozása a bugaci ôsborókásban). Mindezek okai és lehetséges megoldásai, valamint reflektáltságuk is más és más lehet, és éppen e sokrétûség miatt értelmetlen annak kijelentése (szinte minden hozzászóló által), hogy a környezeti válság globális vagy lokális természetủ. Olyan ez, mintha azt mondanánk, hogy a társadalom nôies vagy férfias. A környezeti jog nemzetközi jogként született meg, a globális klímavédelmi egyezmények per definitionem globálisak, az élőhely-védelem $a b$ ovo lokális és helyhez kötött. ${ }^{2}$

Elég nehéz mit kezdeni a Dányi Endre által idézett vitával (Dányi, pp. 5-6.) is, mely azt lenne hivatott eldönteni, hogy a környezeti problémákra a fogyasztás és a népesség korlátozása, vagy pedig a technológia fejlesztése lehet a válasz (tehát az egyik megoldás a felvetés szerint kizárja a másikat!). A környezetterhelés egyik egyszerû képlete azonban ez:

$$
\mathrm{L}=\mathrm{P} \times \mathrm{W} / \mathrm{p} \times \mathrm{U} / \mathrm{w}
$$

Azaz a környezet terhelése a lakosság számának, az egy főre jutó fogyasztásnak és a fogyasztási egység előállításából eredő környezetterhelésnek (magyarán a technológia hatékonyságának) a szorzatából adódik. Azaz nincs semmi értelme szembeállítani a népesség és a fogyasztás csökkenését a technológiai fejlődéssel, mert ha a szorzat bármelyik eleme növekszik, akkor a környezetterhelés is nő, ha egyidejüleg

\footnotetext{
${ }^{2}$ Az valóban jogos kritika lehet, hogy a zöld mozgalmak ideológiájában (de nem a zöld szervezetek által készített szaktudományos elemzésekben!) sokszor idealizált a lokális kötôdés, de a környezeti kérdés fenti leegyszerúsítő jellemzése nem megengedhetô.
} 
egy másik elem nem csökken. És ugyanúgy, hiába csökken valamelyik elem, ha ez a csökkenés magával hozza egy másik elem növekedését, például akkor, ha egy kevésbé környezetszennyezô technológia következtében jelentôsen megnő az egy főre esô fogyasztás. A környezeti válság elkerülése mindhárom elem csökkentését igényli, mert a földi környezet terhelhetősége véges. Ennél biztosabb tény kevés van. Az már bonyolultabb kérdés, hogy ez hogyan oldható meg. Hipotézisként megfogalmazható, hogy minél nagyobb szerepe van a lakosság fogyasztási attitűdjeinek, viselkedésmódjának egy környezeti probléma előidézésében, annál nagyobb szerepet kap a szemléletformálás és ezen belül a média (erre még később visszatérek), és minél tisztábbá tehetô egy adott technológia, annál inkább érdemes abba befektetni. ${ }^{3}$

A környezetterhelés mértékegysége sok minden lehet. Lehet bármilyen emiszszió: ha például a globális klímaváltozásra ható tevékenységeket vizsgáljuk, jó mérőszám a kibocsátott üvegházhatású gázok mennyisége. A környezetterhelés leggyakoribb mérôszáma jelenleg az ökológiai lábnyom (Wackernagel - Rees, 2001), melynek meglehetősen sok számítási módja van, és az a lényege, hogy egy adott földterületen előállítható, évről-évre megújuló terményt és annak energiáját veszi számításba. Mindenesetre elég sok számítás készült ahhoz, hogy egy-két alapjellegzetesség megállapítható legyen. Azonnal cáfolható például az a kijelentés, hogy „nem a városi ember pusztítja a természetet":* egy városi lakos ökológiai lábnyoma nagyobb, mint egy falusi lakosé, de azt is lehet tudni, hogy egy észak-amerikaié nagyobb, mint egy magyaré; egy húsevőé, mint egy vegetáriánusé; egy autóval ingázó dolgozóé, mint a tömegközlekedési eszközök utasaié (minden más dimenzió egyezése mellett). A legmegdöbbentőbb adatok azok, amelyek egy-egy ország vagy kontinens környezetterhelését mérik: a nyugati országok teljes megújuló biológiai kapacitásuk tíz-tizenötszörösét, Magyarország a magáénak két-háromszorosát használja el. Magyarul: a fejlődő országok erőforrásait és a kimerülőben lévő földtörténeti tartalékokat éljük fel. A környezeti válság nem hoax, hanem jól dokumentált és nyilvános statisztikákból ellenőrizhetô folyamat - az más kérdés, hogy jóval nehezebb róla tudomást szerezni, mint a Hilton lányok bugyijának színéről. (Erről késốbb.)

Nem igazán lehet mit kezdeni Sükösd Miklós kritikusainak szóhasználatában azzal sem, hogy mivel „hosszú távon mindenki meghal”, attól, hogy „valaki meghal” vagy „valami elenyészik”, semmilyen szinten nem különül el az, hogy „valakit kiirtanak” vagy „valamit kipusztítanak”. A „nem feltétlenül ontológiai tragédia, ha eltûnnek a bazsarózsák” (Dessewffy, p. 3.) kijelentés csak azzal nem számol, hogy ezek a növények nem pusztulnának ki, ha egy alapvetően pszichopata tevékenység (a háború, azaz a fajtársak megsemmisítése) következtében nem akarnák kiirtani őket. A szemlélet abszurditását szeretném szemléltetni, egy „a rendszer logikájából követke-

\footnotetext{
${ }^{3}$ A Föld szintjén nézve a képlet lefordítható nagy földrajzi régiókra: a fejlett nyugati kapitalista országoknak a fogyasztás visszafogásában, a volt szocialista blokknak a technológia fejlesztésében, a harmadik világnak a népességrobbanás területén kellene elsősorban eredményeket felmutatniuk.

* Az idézett kijelentés Hammer Ferenc vitacikkének átdolgozott változatából, mely lapzártakor érkezett meg szerkesztőségünkhöz, kimaradt. Helyette a következô mondat szerepel: „Amennyiben a tudatos kétkezi természetpusztítást is természetpusztításnak tekintjük (gyomirtózás, malacdopping, vakondvadászat, vegyszeres szúnyogirtás, rapsickodás, illegális hulladékbányák stb.), akkor feltúnhet, hogy ezt nagyobbrészt a kevesebb médiát fogyasztó lakosság követi el." - Lektor.
} 
ző szükségszerú áldozat” jellegú példán bemutatva: Végül is „nem feltétlenül ontológiai tragédia", ha napalmban megfőzik a drezdaiakat, hisz Drezda bombázásának százhatvanezer áldozata „hosszú távon úgyis meghalt volna”. Nem moralizálni akarok, hanem a mondat és a szemléletmód értelmetlenségére hívnám fel a figyelmet: ne kutassuk a terrorbombázás okait és következményeit, mert ontológiai/metafizikai eredménye előbb-utóbb úgyis bekövetkezett volna. A világ megismerésének értelmes voltáról, vagy a kikerülhetetlen Fátum miatti értelmetlenségérôl van szó (részemrôl az előbbi mellett szavazok), nem pusztán az etikai vonzatról. ${ }^{4} \mathrm{~S}$ ha már ennyire sikeredett eltérnem a tárgytól, azt a kérdést azért - dolgozatomban az utolsó metafizikai kérdésként - még feltenném, hogy feltétlenül ontológiai tragédia-e, ha eltűnnek az emberek. (Abszurd kitérô vége.)

Egy faj eltûnése még nem feltétlenül jelenti egy ökoszisztéma összeomlását (bár van erre is példa), azonban a rendszer minden egyes faj eltűnésével labilisabbá válik. Jelenleg az emberi tevékenység következtében oly gyorsan tûnnek el fajok tömegei, hogy ez már a természeti rendszerek fennmaradását és regenerálódását veszélyezteti. Nemcsak a bioszféra egyensúlyának önértékéről vagy metafizikai, etikai kérdésrôl van szó: a biológia sokféleség csökkentése az emberiség életben-maradási esélyeit csökkenti. Tudja-e például bárki, hogy nem a bánáti bazsarózsa egyik fehérjéje lesz-e a rák ellenszere? Vagy hogy nem a balatoni szivacs termeli-e a Balaton vízminőségének fenntartásában alapvető fontosságú enzimet? Hasonló „extrém” példákkal teli van az ökológia. Mindenfajta moralizálás nélkül le lehet szögezni: meglehetôsen kockázatos hagyni, hogy életesélyeink romoljanak.

A környezeti kockázat fogalma és kérdései körül is felmerültek zavarok a vita során. A kockázat egy rendszer működésének bizonyos valószínűséggel bekövetkezô káros következménye. (Szemben a veszéllyel, mely nem egy adott rendszer múködéséből fakad, hanem külsődleges fenyegetettség.) A kockázat létrejöttében ez a valószínűség, a következmények káros mértéke, illetve „felvállalhatósága” a társadalmi tényezô - ha a kár bekövetkezik, akkor hatása már nem a társadalmilag konstruált világtól függ. Az atomenergia kockázatos mivoltát tekintve társadalmi vita tárgya lehet mondjuk annak a valószínúsége, hogy nem kontrollált láncreakció következik be (INES skála 7.), vagy hogy radioaktív izotópok kerülnek a környezetbe nagy mennyiségben (INES skála 5-6.). Elvben „ezer évben egy” ilyen baleset várható, ehhez képest azonban ötven év alatt egy INES 7. és három INES 5-6. besorolású esemény történt. Szintén társadalmi vita és kockázatelemzés tárgya lehet, hogy mit számítunk bele az atomenergia elôállításának folyamatába (az uránbányászatot és az általa okozott, megvalósult ártalmakat, valamint az ebből valószínúsíthető kockázatokat is, vagy csak a reaktorokban történteket). További kérdés, hogy a haszon arányban áll-e a kockázatokkal (megéri-e ötven évente egy-egy Three Mile Island, Windscale, Kistim, vagy

\footnotetext{
${ }^{4}$ Bár lehetne akár etikai vonzatokról is beszélni: Következik-e egy tevékenység következményeinek felismerésébôl valamilyen szintũ felelôsség-minimum? Az ökoetika szerint igen, ám vannak olyan etikai rendszerek, amelyek szerint nem. Egy tralfamadorinak például, aki a világ összes pillanatát egyben látja, nehéz lenne megmagyarázni a drezdaiak pusztulásának etikai vonzatait (Vonnegut, 2004). Ha az etikai keretek feszegetése meghaladja is a dolgozat témáját, a jogi keretek leszögezése nem: a Cartagenai jegyzônkönyv alapján az államok kötelessége megốrizni területükön a fajtagazdaságot, azaz egy faj eltüntetésére irányuló tevékenység nemzetközi jogot sért, ugyanúgy, mint a háborús búncselekmények vagy a védổaámok alkalmazása.
} 
egy Csernobil a nem is olyan olcsó energiát, ha vannak helyettesítô megoldások). Az a tény már nem társadalmi konstrukció (legfeljebb képzeteinket konstruáljuk meg társadalmilag), hogy ha egy élőlényt elég sok radioaktív sugárzás ér, akkor belepusztul. (Nem mellesleg szólva, száz százalékos valószínűségủ kockázat már nem kockázat, hanem bizonyosság - a fenti négy esetben.)

A hozzászólásokat olvasva néha olyan érzése támadhat a hozzászólónak, mintha a kockázat-elemzés nem a valóság empirikus megismerhetőségébe vetett hit, hanem a szubjektív idealizmus talaján állna (,és most már azt hiszem, hogy nincs igazság, / már azt, hogy minden kép és költemény, I aะt, hogy Dsuang Dsi álmodja a lepkét, I a lepke ốt és mindhármunkat én." - Szabó Lőrinc), holott a tudományos megismerés alapja az a meggyőződés, hogy a valóság megismerhetô. A kockázat nem teljesen szabadadon meghatározható, konstruálható, álmodható, negligálható vagy felnagyítható: a valóság ott motoszkál az eltérō értékfelfogások és ésszerűségek alapján meghatározott, konstruált, felnagyított, negligált kockázatok mögött. A környezeti kockázatok felmérésében a nehézséget egyrészt a környezeti kockázatok rendkívül összetett mivolta, sokszor többszörösen közvetett hatása adja, ami a valóságkonstrukcióktól függetlenül is hatás, csak érvek közvetítik. (A DDT nem akkor kezdett el mérgezni, amikor Rachel Carson Néma tavasza már megjelent.) A nehézséget másrészt az adja, hogy a kockázatok megkonstruálása és észlelése eltérô világlátások és értékválasztások alapján zajlik: „a kockázatokkal foglalkozó vitákban nyilvánvalóvá válnak a tudományos és a társadalmi ésszerűség közötti szakadékok és árkok a civilizációs veszélyforrásokkal kapcsolatban" (Beck, 2003:42, kiemelés az eredetiben). Ezek alakulásában és a közöttük való közvetítésben viszont kiemelt szerepe lehet a médiának, a nyilvánosság e fontos eszközének is: a kockázatok „tudásban jönnek létre [és] kiváltképpen nyitottak a társadalmi meghatározási folyamatok számára. Emiatt társadalmi-politikai kulcspozíciókat töltenek be azok a médiumok, amelyekben a kockázatok meghatározása történik" (Beck, 2003:31, kiemelés az eredetiben). Sükösd Miklós téziseit kérdéssé formálva: a kereskedelmi média vajon ilyen médiumnak tekinthetô-e?

\section{MODERNITÁS ÉS MÉDIA}

Sükösd kritikusai két általános, nem közvetlenül a tézisekhez kötôdô kritikát fogalmaztak meg: a) a média elemzése modernitás-kritikát fed, így a médiának tulajdonít olyan hatásokat, amelyek a modern gazdasági-technológiai-társadalmi rendszer más elemeiból következnek, ráadásul b) a média nem tipizált, a Sükösd által használt médiafogalom nem elég árnyalt.

Sükösd médiaelemzésében a kritikusok egyrészt azt kifogásolják, hogy a modernitással kapcsolatos - akár jogos - fenntartásokat rávetíti a médiára, másrészt a médiának túl nagy szerepet tulajdonít. A kiindulópontul szolgáló tézis: „a társadalom mediatizációja hozzájárul az ökológiai válság elmélyüléséhez, vagyis tulajdonképpen oksági kapcsolatban állnak egymással.” (Sükösd, 2003:132.). Sükösd hozzáteszi rögtön, hogy a kapcsolatot közvetettnek feltételezi. Az oksági jelzővel valóban csínján illene bánni, ennyiben jogos a kritikusok észrevétele, de a dolgozat csak azt állítja, hogy van ilyen hatás, míg azt sehol sem, hogy ez a hatás kizárólagos, vagy egyetlen. Szerencsésebb lett volna a „társadalom mediatizációjának jelenlegi formája hozzájárul a kör- 
nyezeti válság elmélyüléséhez, vagyis aa modern gazdasági-technológiai-társadalmi rendszer egyik olyan eleme, amely más elemekkel együtt hat erre" tartalmú megfogalmazás. Azaz a média csak egy elem egy útmodellben, melynek végén a környezeti válság áll. A modernitáskritikán belül egy intézmény, a média hatásának vizsgálata teljesen legitim törekvés: Sükösd nem is ígér többet, csak szóhasználatával nem teszi ezt egyértelmûvé.

A Sükösd Miklós által feltételezett hatást az alábbi módon ábrázolhatjuk, vastagon szedve azokat az elemeket, amelyeknek a kapcsolatai expliciten ki vannak fejtve a vitaindítóban, és normál betúvel szedve azokat, amelyeket egy-egy megjegyzés alapján a modell részének tekinthetünk.

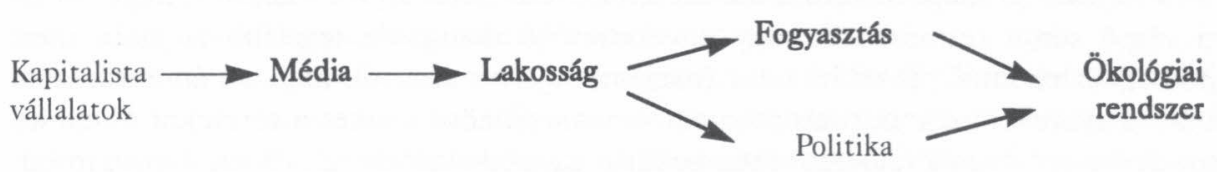

H1:

$\begin{array}{llll}\text { Anti-zöld Anti-zöld } \quad \text { Anti-zöld } & \text { Anti-zöld } & \begin{array}{r}\text { Állapota } \\ \text { romlik }\end{array}\end{array}$

$\mathrm{H} 2$ :

Zöld

Zöld

Zöld

Zöld

Állapota
javul

Sükösd érvelése szerint a (kereskedelmi) média tájékoztatási hiányosságaival, fogyasztásgenerálásával, a valóságtól elcsábító alternatív világ teremtésével anti-zöldként írható le, azaz egy nem fenntartható tevékenység egyik kiindulópontja (H1). Sükösd Miklós téziseiből nem derül ki, hogy hipotézise szerint ha a média zöldülne, az a lakosság és ezen keresztül a fogyasztás, a választói igények zöldülését, tehát végsổ soron az ökológia rendszer kímélését hozná-e magával (H2). A „kevés a tájékoztatás” tézisbő́l ez következne, a „két valóság van” tézisből nem. Lányi András hozzászólása alapján az ökológiai kérdések erőteljes megjelenésének a médiában nem lenne hatása a rendszer egészének és a modern ember világának újrakonstruálása nélkül.

Nemcsak ennek a kifejtése hiányolható. Egyet kell érteni a kritikusokkal abban, hogy Sükösd a médiának néhol túl nagy szerepet tulajdonít, vagy legalábbis nem szögezi le a média és más elemek hatásának határát. A média (jelenlegi formájának) hatását a környezeti válságra a fớbb hatóelemeket is felvonultató, útmodell-jellegû̉ elemzés keretében tartanám elképzelhetônek, jelezve, hogy a média hol erősíti fel, esetleg hol gyengíti azok környezetromboló hatását. Vázlatszerúen tehát fel kellett volna tüntetni, hogy melyek azok a legfontosabb elemek, amelyek ennek az útmodellnek a részei és a környezeti válságra független váltózóként ható elemei. A kritikusok számos ilyen elemet felsoroltak: a) a pénzügyi rendszer sajátossága, a hitelek fogyasztásgeneráló hatásától a spekulánsokig; b) az urbanizáció; c) a nem hatékony technológia. Ezekhez hozzátehetố még számos elem, például d) a mesterségesen ma- 
gas humán erőforrásköltségek, szemben a mesterségesen alacsonyan tartott természeti erőforrásköltségekkel; és e) a gazdasági tevékenység externália-leíró lehetősége, a végsố soron a környezetkárosító tevékenységeknek kedvezố és a környezetkímélô tevékenységekre nézve hátrányos szabályozás, stb. ${ }^{5}$

A kritikusokkal egyetértve: a rendszer más elemei sokkal jelentősebbek tûnnek, nem a média teszi környezetrombolóvá a rendszert (ha egyáltalán). Nem azért autózunk (16-18 éves kor felett), mert az a „trendi”, hanem mert máshogy nem tudunk eljutni otthonunktól a munkahelyünkre. A kritikusokkal szemben viszont nem állítható, hogy a média szerepe elhanyagolható lenne. Csak a média szerepe más (és a vitaindító dolgozat az én olvasatomban nem is állít többet). A média hozzájárul (nem kizárólagosan) ahhoz a létező imázshoz, hogy az új és jó autó a sikeresség záloga, tehát a teljesen jó állapotú autó is lecserélendő; hozzájárul ahhoz a képhez, hogy autózni végsố soron természetes vagy egyenesen jó dolog, de legalább is jobb, mint „tömegközlekedni”. Továbbá nem (nagyon) tájékoztat arról, hogy az én autózásom miatt a gyerekemnek asztmás rohamai vannak. Sükösd ezeket a tételeket emeli ki, hozzátéve azt, hogy a valóságot szembeállítja a „médiavalósággal”. Beck alapján mindezt a médiának a környezet és a kockázatok észlelésében megkonstruált szerepével lehet kiegészíteni.

Beck - és a Greenpeace kommunikációs sikereit felemlegetôk - képzetei szerint a kockázatok meghatározása, a környezet képzetének kialakítása nagy nyilvánosság előtt, a nagy nézettségű médiában zajlik, ez a „meghatározási harc” terepe. „Mindenütt, ahová az okokat kereső reflektor bevilágít, rögtön felizzik a tûz, s a gyorsan öszszehívott és nyomorúságosan felszerelt 'érvelés-tűzoltóságoknak' az ellenérvek teljes sugarával kell oltania és mentenie, ami eloltandó és ami mentendő. Aki hirtelen a kockázattermelés nyiloános pellengérére kerül, amennyire tudja, a lassan üzemi szinten intézményesített 'ellentudomány' segítségével cáfolja az ốt pellengérre állító érveket és más okokat, s ezáltal más okozókat említ fel. A kép egyre változatosabbá válik. Központi jelentôségü lesz a média beavatkozása. Az iparon belül fokozódik a bizonytalanság: senki nem tudja, kire csap le legközelebb az ökológiai morál. Jó vagy legalábbis nyilvánosan érvényre jutó érvek válnak az üzleti siker feltételévé. A nyilvánosság munkásai, 'az érvelés ácsmesterei' szakmai esélyt kapnak." (Beck, 2003:45, kiemelés tôlem.)

A kockázatok mibenlétének különféle alkuk eredményeként történő meghatározása, és ezáltal a környezeti szabályozás kialakítása terén azonban - úgy tûnik - bonyolultabb a kép. Ezen a téren nagyobb szerepet kapnak azok a középszintû nyilvánosságok (Tamás, 1999:258), ahol egy-egy csoport kialakítja kockázat-észlelését és azok a fórumok (szakmai konferenciák, politikai egyeztetető tanácsok, szektorközi találkozók) is, ahol ezek a résznyilvánosságok találkoznak, gyakran nagyobb publicitás nélkül. A meghatározási harc terepének nagy része azonban nem kap széleskörû publicitást: a nagyarányú médiavisszhang a már létező egyeztető folyamatokra erősít rá, illetve a közvélemény mozgósításával ezekre hat.

\footnotetext{
${ }^{5}$ E problémák mindegyikére van „zöld”, környezetkímélố válasz, a Tobin-adótól kezdve az ökoadón és a tömegközlekedés fejlesztésén át a zöld városrehabilitációs tervekig.
} 
A három legismertebb példa erre a három legismertebb környezetszabályozási egyezmény. A DDT használatának szabályozása és betiltásának gondolata már az ötvenes években felmerült (például az amerikai élelmiszer- és gyógyszer-hatóság jelentéseiben). Rachel Carson 1962-ben megjelent és hatalmas botrányt kavart könyve, amelyet sokan a környezetvédelmi diskurzus nyitányának tekintenek, egy létező nyomásgyakorlásnak és érvrendszernek adott rendkívül erős lökést. Hasonló a helyzet az ózonréteget károsító $C F C$-kibocsátás korlátozásával: amikor az angol királynố nagy feltûnést keltett és példát mutatott azzal, hogy inkább lecseréli kedvenc parfümjét, mintsem freon-gázos kivitelben tovább használja, a tiltás kialkudása már elôrehaladott állapotban volt. A globális klímaváltozás szabályozását szolgáló, szintén nagy nyilvánosságot kapott kiotói egyezmény előkészítése után szaporodtak meg a tudósítások a jelenségrôl. (Beck - míg idézett írásában a „nyilvános pellengért” tekinti elsődlegesnek - maga is szorgalmazza ilyen fórumok létrehozását.)

A média tehát a kockázatmeghatározási harcnak csak az egyik terepe, és hatását főleg a közepes szintû nyilvánosságokban folyó meghatározási harc kimenetelének befolyásolásában, bizonyos vélemények diszkreditálásában, illetve felerôsítésében, valamint az ott kialkudott új status quo legitimálásában fejti ki. Két másik - nem környezetvédelmi - emancipatórikus példán is szeretném e folyamatot érzékeltetni: A feminista áttörés jogelméleti és társadalomelméleti viták keretében indult a hatvanas években, s ezt a média beszédmódjának megváltozása és a minták megváltozása (fôleg a szappanoperákban) a hetvenes-nyolcvanas években felerôsítette. Az észak-amerikai faji előítéletek leküzdésében is a jogi szabályozás megváltozása volt elsődleges az ötvenes években, s ezt erősítették fel a hatvanas évek emberi jogi médiaakciói. E törekvések eredményeként végül a hetvenes évek végén megjelentek az afroamerikai filmsztárok. (Ezekre a példákra később még egy mondat erejéig visszatérek.)

A modernitás egészén belül érdemes tehát elhelyezni a média szerepét. De milyen médiának a hatásáról szól Sükösd? A vitaindító egyértelmûvé teszi, hogy elsôsorban a nagy nézettségû̉ kereskedelmi médiáról. „Média alatt itt elsôsorban a népszerû, kereskedelmi alapon múködő tévék, rádiók, újságok, internetes tartalomszolgáltatók sokaságát (a fősodrú médiát) és a közmédia nagy részét, valamint a bennük uralkodó médiamúfajokat, kánonokat, reprezentáció-típusokat értem" (Sükösd, 2003:132-133). Nem jogos tehát az a kritika, hogy a vitaindító egybemossa a régi és az új médiát. Jogos azonban Pintér észrevétele: médiumok és műfajok szerint tagolni kellene a megállapításokat - ezek mentén nyilván más és más a környezeti válság megjelenítésének hiányossága vagy a feltételezett fogyasztásgenerálás. Sükösd Miklós állításai alapján a mainstream média fogalmát a kereskedelmi tévék híradóira, showműsoraira és a reklámokra lehetne leszúkíteni, miközben a médiafolyam nemcsak ezekbôl áll. Egy médiumtípust és egy múfajt rögtön kiemelhetünk, melyekre nagy valószínûséggel nem érvényesek Sükösd megállapításai. Az életmód- és női magazinokban egyértelmûen kimutatható a többnyire alternatív életmód- és wellness-imázsba csomagolt ökotudatos szemlélet és imázs. A játékfilmek terén is erốteljesen jelen van a zöld tematika, a B kategóriájú filmek akcióhősei a nyolcvanas évek óta környezetszennyező banditáktól mentik meg a világot, a katasztrófahelyzeteket nem külső veszély vagy ellenséges hatalom, hanem a környezeti válság okozza, ső́t még a Steve Martin-féle komikus filmekben is legalább egy jelenet erejéig szerepet kap a környezetszennyezés káros volta. 
A részletesebb tipológia hiányánál fontosabb az új média, az internetes kommunikáció hatásának elemzése (illetve Sükösdnél annak hiánya). Ennek megjelenése legalább két nagy változást hozott: a) lehetôvé tette a fent említett középszintû nyilvánosságok megszervezését globális szinten, s így rendkívüli módon felerősítette a környezetvédő mozgalmak hálózatosodását és globális szinten való fellépésének lehetôségét: „A számítógépekben benne rejlik a lehetôség, hogy kiterjesszék az ember ismereteit a környezetról és arról, hogy milyen hatással vagyunk a környezetre. [...] Globális szemeket és füleket adhatnak nekünk egy olyan korban, amikor tetteinknek gyakran az egész világra kiterjedő hatásai vannak" - jósolta John E. Young 1993-ban (Young, 1994:115). Másrészt b) az Internet alapvetốen kikezdte azt a hegemón (de sohasem tájékoztatási monopólium) helyzetet, amit a nagy tévétársaságok, hírügynökségek élveztek. A „Zöld Pók”-hoz, a greenfo-hoz vagy az indymediá-hoz hasonló fórumok viszonylag erôs kritikai kihívást jelentenek a kereskedelmi vagy közszolgálati médiumok számára a tájékoztatásban. (Olyannyira, hogy a mainstream tájékoztatási csatornák egy része az utóbbi években alternatív, zöld rovatokkal gazdagodott, mint például a Népszabadság online változatának alternatív rovata.)

Az internetes és digitális kommunikációnak környezeti szempontból más hozadéka is lehet: kiválthat nagy környezetterhelést okozó tevékenységeket, technológiákat (ide tartozhat a postai és archiválási célokra használt papírnak és a sokszorosító technológiák vegyszerigényének kiváltása, a távmunka által kiváltott ingázás). A képlet azonban - mint Young a Szilikon-völgyrôl szólva rámutat - nem egyszerú, ,a valóságban a számítógépgyártás nem olyan tiszta, mint ahogyan azt az iparág zöldellő irodai parkja sugallná. Az elektronikai ipar számos mérgező vagy a környezetre veszélyes anyagot használ, s ezek közül sok kiszökik a munkaterekbe és a környezetbe. [...] Az Egyesült Államokban ebben a völgyben találhatók a legsưrúbben a veszélyes hulladékok lerakóhelyei, talajvízének nagy részét triklór-etilén (TCE) [...] és számos más vegyszer szennyezi, amelyeket az elektronikus alkatrészek gyártása és tisztítása során használnak." (Young, 1994:110) Az infotechnológiai ipar környezetterhelését jelentősen növeli a rendkívül gyors fejlődés, ami a gépek gyors cseréjét követeli meg. Sükösd víziója a vegyszerektôll bűzlő patak partján álló világhálóra kötött házról nem is annyira vízió.

A nem részletezett mainstream médiával kapcsolatos hét pontba szedett sükösdi téziseket a hosszúra nyúlt bevezetố után az alábbi három pontba sûrítve vázolnám a továbbiakban: a környezeti válság megjelenése a médiában, a média hatásai, továbbá a „médiavalóság” és a „valóság” szembeállítása.

\section{A KÖRNYEZETI KÉRDÉS MEGJELENÉSE A MÉDIÁBAN}

Sükösd Miklós határozott tézise, hogy a kereskedelmi médiában nem jelenik meg a környezeti válság. „A média azonban általában nem tartja fontosnak a környezetei napirendet", mert a) a médiatartalom egészében a szórakoztató mûsorok dominálnak, b) a tájékoztató músorokban az uralkodó elitek játszanak meghatározó szerepet, a környezetei válság pedig csak látványos katasztrófaként jelenik meg. Ráadásul, ha mégis felbukkan a környezeti válság kérdésköre, akkor ez c) nem kontextusával együtt, a maga bonyolultságában megjelenítve, hanem d) a mûsorfolyam egészéhez 
igazítva, a „minden rendben megy, minden kezelhetô” képzetet keltve kerül a képernyôre.

A kritikusok teljes joggal teszik szóvá, hogy a helyzet nem ennyire fekete-fehér, és sorolják azokat a példákat, amelyek a környezeti kérdés előtérbe kerülését, vagy akár bonyolultságának pontos és érdekes bemutatását bizonyítják: csak meg kell tanulni „csomagolni”, hogy a környezeti kérdések megállják a helyüket a hírversenyben. A kritikusok azt a hibát követik el, hogy míg rámutatnak arra, hogy a helyzet nem fekete-fehér, azt nem jelzik, hogy mennyire tekinthetô sötétnek vagy világosnak, azaz a számonkért arányok és árnyalatok kérdése nem kap teret. Egyfelôl mennyire könynyú a média számára csomagolni, másfelől mekkora és milyen minőségû az a mégiscsak megjelenő adag, ami a vitaindító által jelzettnél többnek tűnik?

Elôször a csomagolásról: A környezeti kérdések hírértékké csomagolása eleve nehéz, mert sokszor nagyon bonyolult és hosszú távú folyamatokról van szó. De e tartalmi kérdéssel egyenértékűnek tûnik egy formai kérdés is: Milyen lehetôségeik vannak a csomagolóknak? A legnagyobb hazai zöld szervezeteknek egyenként néhány százezer forintjuk van kommunikációs célokra. Egy erômű́nél vagy egyéb nagy környezetterheléssel gazdálkodó nagyvállalatnál ez az összeg százmilliós nagyságrendû́. Egy nemrég végzett felmérés (ELTE Társadalomtudományi Szakkollégium, 2004) szerint még a legnagyobb zöld szervezetek sem engedhetik meg maguknak a listaárnál 80-90 százalékkal olcsóbb társadalmi célú reklámok igénybevételét, néhány nagyvállalat pedig akár még teljes mûsort is vehet szponzorként. Nyugaton sem rózsásabb a helyzet, az egyetlen Greenpeace kivitelével, amely kifejezetten kampányszervezet.

Ebből a szempontból - Hamburger Béla hozzászólásával ellentétben - a reklám nem semleges eszköz. A reklám a tehetốsek kommunikációs eszköze. Hiába néhány (saját életét kockáztató) tényfeltáró újságíró kitartása és számos civil (polgári pert kockáztató) szervezet kampánya, hogy felhívja a figyelmet egy olajcég környezetpusztító és népirtó, Nobel-díjas írót kivégzô tevékenységére Nigériában, ha a cég erre válaszul a világ legjobb reklámszakembereivel elkészíttet egy tökéletes spot-ot és telerakja vele a Föld összes jelentős kereskedelmi TV csatornáját. Hiába egy bányacég által ledarált falu lakóinak tüntetése, amikor a cég Photo Shop-pal feljavított panorámaképen mutatja be, hogy a külszíni bánya mellett élni valójában a földi paradicsom. A legalább részben hiteles tájékoztatás, vagy egy cég fenti üzleti tevékenységének megállítása a nyilvánosság eszközeivel ilyen esetekben szinte reménytelen.

A greenwash jelensége, vagyis az a törekvés, hogy egy környezetpusztító cég magáról környezetbarát imázst alakítson ki (Fidrich, 2003), a hiteles tájékoztatás súlyos torzításához vezet - mind reklámok, mind megfelelő hírértékek gyártásával. („X cég a természet védelmében" cikksorozat: csinos tájékozató központ létrehozása vagy egy olyan intézmény támogatása, amely a természetvédelem szolgálatában áll, esetleg egy környezetvédelmi díj alapítása, pogácsás-kacsamájas sajtótájékoztató, fotósorozat lehetőleg egy NatGeo munkatárstól, helyszíni látogatás neves vendégekkel, mindez néhány millióból, ami a cég számára nem tétel).

A médiacsomagolás terén megfigyelhetố bolha vs. elefánt felállás (a kommunikációra fordítható források közötti százszoros, ezerszeres különbség) ellenére a cégek és az intézmények „zöld imázs” kialakítását célzó tevékenysége nem feltétlenül káros környezeti szempontból. Egyrészt - fóleg az utóbbi évtizedben - az imázs mögött néhány cég esetében valódi környezetjavító tevékenység, környezetei felelősség áll, egyre gyakoribb például zöld civilek bevonása a cégek tevékenységének környezetvé- 
delmi szempontból történő átvilágítására. Másrészt viszont a környezeti felelőtlenség eltakarására szolgáló kommunikáció felerôsíti és még legitimebbé teszi a környezeti kérdést.

Sükösd Miklós „környezeti tájékostatáshiány” tézisének legjobb bizonyítéka a vita menete: a kritikusok számos ökológiai alapismeretre és eseményre nem reagálnak, hisz nem szakterületük - így arra hagyatkozhatnak, amit a médiából, pontosabban a híradókból és a minôségi sajtóból mûvelt polgárként megtudhatnak. Ennek alapján pedig nem is olyan nagy a gond: a fejlett Nyugaton nő a várható élettartam, csökken a csecsemőhalandóság - ilyen híradások megjelennek a hetilapok éves összefoglalóiban.

A többi statisztika kevésbé fényes, de ez nem került elő a kritikusoknál. A várható élettartam Afrikában és a Közel-Keleten például csökken. Magyarországon az elmúlt tíz évben megháromszorozódott az asztmás megbetegedések száma, már minden harmadik gyereknek légúti megbetegedése van, növekszik a szintén levegốszennyezés által okozott légcső-, hörgő- és tüdőrák miatti korai halálozás, nô a bôrrák és a szürkehályog gyakorisága (tíz évente tíz százalékkal, annyival, amennyivel az ózonréteg csökken). (Jakab, 2004; Virágh, 2004) A létezô nemzetközi programok és a hazai stratégia (Nemzeti Környezet-egészségügyi Akcióprogram) dacára nem sokat sikerült javítani a környezet-egészségügy helyzetén, a környezetszennyezés továbbra is az egészségünkre, végső soron az életünkre megy. Vannak pontok, ahol sikerült áttörést elérni, például a nehézfém-szennyezések területén. Azaz valóban tovább élünk, csak betegen és rokkantan, amit a környezeti ártalmak okoznak. Erről azonban a média nagy része nem tudósít.

2004. júniusában az - Európa összes egészségügyi és környezetvédelmi miniszterének részvételével Budapesten tartott - ötéves ciklust lezáró negyedik európai környezet- és egészségügyi miniszteri konferencián követendő nemzetközi stratégiaként elfogadták az úgynevezett $C E H A P E$ programot a gyermekek egészségének védelmére, $s$ ráadásul lezárták a forgalom elôl a BAH csomópontot is. A hírértékhez tehát minden adott volt. Ehhez képest két hazai napilap tudósított az eseményrôl. Ugyanekkor zajlott le a soros NATO-csúcs Isztambulban, semmi különösebben érdekes témával vagy eredménnyel. Minden napilap és hetilap részletesen foglalkozott vele.

Alapvetố környezeti információk nem jelennek meg a sajtóban. Különféle országok GDP-jének összehasonlításáról bármikor olvashatok bármelyik közéleti lapban, de még tabloidban is. Ugyanezen országok ökológiai lábnyomáról nincs híradás. Minden nap megtudhatom a budapesti értéktôzsde adatait vagy a valutaárfolyamot, a $B U X$ indexet. Az aznapi kén-dioxid vagy szén-monoxid kibocsátást, az UV sugárzás mértékét nem - pedig ezek az aarhusi egyezmény alapján ráadásul olyan közérdekű adatok, amelyekhez minden állampolgárnak joga van hozzájutni, s ezért az illetékes hatóságok kötelessége, hogy nyilvánosságra hozzák őket. Nyilván nem lehet számonkérni a sajtón, ha a kormányzat egy alapvető jogot nem tud biztosítani, de a Sükösd által megállapított helyzet fennáll - ám megint nem olyan fekete-fehéren: a sajtóban öt-tíz éve megjelentek a zöld rovatok, amelyek valamelyest hiánypótlónak számítanak, illetve a web-nek köszönhetőnek létrejöttek alternatív tájékoztatási fórumok, ahol a fentiekhez, ha nehezen is, de hozzájuthatunk.

Az alapinformációkhoz való hozzájutás nehézségén túl maguknak a környezeti kérdéseknek az elhelyezése is a hátrányos helyzetet tükrözi. Nyilván nem bizonyító erejû, de meglehetôsen módszeres eredmény: a cikk írása közben (két héten keresz- 
tül) a és a www.origo.hu portálok nyitólapján minden másnap találtam írást a kétségkívül csinos két Hilton lányról. Az EU klímavédelmi intézkedéseirôl, amelyek 2005-tôl kezdve alapvetốn meghatározzák a nagy széndioxid-kibocsátó gazdasági szereplők tevékenységét, és végrehajtásukhoz most építik ki az intézményrendszert, rákereséssel egy híradást találtam. A közlekedési eszközök, s köztük a személyautók széndioxid-kibocsátására vonatkozó szabályokat szintén most dolgozzák ki - ezek több állampolgárt érintenek, mint a fent említett lányok. A korallzátonyokról megtudhatom, hogy most már hetvenezerért is búvárkodhatom közöttük, de összesen két rövid - csak online verzióban megjelent - napilap-cikket találtam az elmúlt évben arról, hogy a korallzátonyok széndioxid-megkötő képessége, illetve ennek felengedése a Föld (Gaia) önszabályozó rendszerének egyik legfontosabb részét alkotja... A környezeti kérdésekről lehet tájékozódni, de a környezeti kérdés nincs a figyelem középpontjában.

Külön vita alakult ki a természetfilmek megítélésérôl. A kritikusokkal egyetértek abban, hogy a természetfilmek fontos információforrást és élményt jelenthetnek. Csakhogy az elmúlt tíz évben alapvetố változás figyelhetố meg ezek jellegében: míg a hetvenes-nyolcvanas években a természetfilmek életközösségeket, tájakat mutattak be, és részletesen körülírták azok müködését, illetve fenyegetettségét, ma már a divatállatok és a nagyobb események (cápák, krokodilok, pókok, tájfunok, vulkánkitörések) dominálnak itt is, a kontextus, az ökológiai összefüggések ábrázolása nélkül, és a környezeti felelősségre felszólító végszók is egyre ritkábbak.

Nemcsak a mennyiségről vagy a műsorszerkezeten belüli elhelyezésről van szó, hanem a nyelvi közegről is. A környezetei érdekeket megfogalmazó állításokkal szemben jelenleg megengedettnek számít a nagyfokú verbális diszkreditáció, a zöld témák megjelenítésének nyelvezete számos esetben diszkriminatív magával a témával szemben. Az amerikai konzervatív sajtóban a környezetvédőket hazaárulónak vagy terroristának nevezni mindennapos dolog. Az itt folyó vita idején, 2004 tavaszától kezdve a magyar sajtóban is meglehetôsen erôs sajtótámadás indult a környezetvédő civil szervezetek ellen. Az amúgy mértékadó és a hiteles tájékoztatásra sokat adó lapok (HVG, Magyar Narancs, Élet és Irodalom) is teret adtak olyan tudósításoknak és publicisztikáknak, amelyek alapján azt állapíthatjuk meg, hogy a hiteles tájékoztatás elveinek figyelmen kívül hagyása, a demokratikus alapelvek megkérdőjelezése vagy akár a fasiszta alapállásból kiinduló uszítás is megengedhetô, ha az a környezetvédő civil szervezetek ellen szól - akár csak oldalvágásként. (Íme néhány példa erre, a durvaság sorrendjében a finomabbnak tekinthetô elsőtől a jogsértés határán mozgó utolsóig, a teljesség igénye nélkül: Tóth Gábor Attila: „Éhhalál Pesten”, HVG, 2004.06.02. Dobrovits Mihály: „Az Új Aranykor mítosza és más történetek”; Búr-Baky Miklós: „Fiatal desperadók, eszelôsök”; uô: „Az establishment koloncai”, Magyar Narancs, 2004.08.12, 2004.05.20, 2004.05.27. Bauer Péter: „Zöld veszedelem”, Élet és Irodalom, 2004. 29. szám.) A már emlegetett feminizmus és antirasszizmus témakörében megjelent cikkekben és azok kritikáiban megközelítóleg sincsenek ilyen jellegû „nem$P C$ ” eszközök.* A „Kínai veszedelem”-hez hasonló címekre, az afféle kitételekre,

* PC: politically correct. (A szóhasználatra kényes mozgalom eredményeire jellemzổ a következổ példa: Agatha Christie egyik híres művének („Tén Little Niggers”) Németországban nem lehet többé „Tíz kicsi néger” a címe. Az angol írónô örökösei ugyanis eleget tettek a Hannover város diszkrimináció-ellenes hivatala által közzétett felhívásnak, hogy adjanak más nevet a regénybôl készült színdarabnak. - Lektor 
mint például az, hogy „a feministák mérhetetlen károkat okoznak a gazdaságnak”, az olyan evidenciákra, hogy „a nemek egyenlősége elvont közcél, melynek alkotmányos védelme káros”, vagy az olyan jellegü kioktatásra, mint pl. „aki tanult történelmet, az tudhatná, hogy a nôk mindig is el voltak nyomva, mit kell jönni a családon belüli erőszak statisztikáival?" ki ne kapná fel a fejét, és ki ne határolódna el rögtön ezektől?

Ám ez a jelenség sem ilyen sötét. Klaus Eder felhívja a figyelmet arra, hogy az ökológia értelmezési keretté vált a nyugat-európai társadalmak nyilvánosságában (Eder, 2000), azaz ilyen delegitimáló, diszkreditáló magatartásnak és nyelvezetnek a jövőben már nincs sok esélye.

A minőségről még egy megjegyzés: a zöld médiakritika egyik sarokpontja, hogy a környezeti válság a rendezett világ keretében vagy legalábbis megoldható problémaként jelenik meg. A kritika eléggé jól alátámasztottnak tưnik. Az olyan állítások, hogy a környezet védelme „újrafelhasználási szakmai kérdés” (Z. Karvalics, p. 4.) kevésbé merülnének fel, ha a környezetpolitika alapvetéseirôl a nagyobb nyilvánosság előtt szólna a diskurzus. Nos, a környezetvédelem mint olyan az 1986-ban elfogadott Egységes Európai Okmány $(S E A)$ életbelépése óta az integrált európai politika egyik alapelve, és az 1992-ben aláírt Maastrichti Szerződés alapján a környezeti szempontok érvényesítése a végrehajtásban is ellenőrizhetôvé válik, vagyis ezeket minden szakpolitika kialakításakor alapelvként kell kezelni, legalábbis az Európai Unió területén. $\mathrm{Az}$ integrált környezetvédelem mindazonáltal még mindig nagyon messze van a fenntartható fejlődéstől, ami az EU göteborgi stratégiájának (2001), valamint a Riói Csúcsnak (1992) is a célkitûzése. (A fogalmat egyébként politikusoknak és újságíróknak egyaránt még most is sikerül felcserélniük a „fenntartható növekedés” abszurdumával...) Erről az átlag újságolvasó, sőt még az aktív érdeklődő is nehezen szerez tudomást: a környezeti kérdések a magyar sajtóban még mindig technokrata megoldásokként vannak tálalva és füszerezve. Kármentesítés, hulladékfeldolgozás, tisztítómû́-építés, határértékek mérése: csupa szakpolitikai megoldás és csôvégi technológia-ismertetés.**

„Tartanák csak fontosnak az emberek a környezeti napirendet, rögtön ezerrel bombázná ezzel őket a média" - szól az ellenvetés a fentiekre (Z. Karvalics, p. 3.) Ezt a mondatot két tény cáfolja: a) fontosnak tartják, b) a médiának nem ez a múködési módja.

A környezet védelme az összes (bár kevés) közvéleménykutatás szerint a három legfontosabb érték és téma között jelenik meg (Magyarországon). Minél közelebb megyünk a lakóhelyhez, annál inkább fontosabbá válik. Ugyanakkor a lakosság nagy része úgy érzi, hogy a környezeti károk és kockázatok elôállításában nem játszik szerepet, azaz nem éreznek felelősséget sem ezzel kapcsolatban. A környezet megóvásáért tevékenykedni a lakosság akkor hajlandó, ha érdekelt az ügyben, vagy az nem jár megerőltetéssel, nagyobb energiabefektetéssel (Szirmai, 1999, Füzesi - Tistyán, 1998, Eurobarométer, 1993, Fact, 1993, Gallup, 1992, 1994). A környezet állapotára vonatkozó információk forrásait kutatva a Magyar Gallup Intézet 1994. évi vizsgálata azt állapította meg, hogy a környezeti problémákkal, környezetvédelmi kérdésekkel kapcsolatban az emberek több mint kétharmada elsôsorban a televízióból informálódik, ** A folyamatok végérốl induló eljárásokat - az angol end-of-pipe terminus tükörfordításával -
„csôvégi technológiáknak" is szokás nevezni. - Lektor. 
ahol a környezeti kérdések alig, illetve csak felszínesen interpretálva jelennek meg. A fentebb említett budapesti környezet-egészségügyi konferencia és a NATO csúcs szembeállítása kapcsán megjegyzem, hogy nem találkoztam még olyan statisztikával, ahol kimutatható lett volna olyan jelentôs létszámú csoport, melynek tagjait jobban érdekelték az iraki hadmúveletek, mint az, hogy ők maguk vagy a gyerekeik rákosak lesznek-e vagy sem.

A magyarázat egyszerû: az a feltevés, hogy a szerkesztôk az olvasók igényei alapján szerkesztenék a lapok tartalmát, egyszerûen mítosz. A hírérték és a „szakmaiság” aktuális felfogása, a világlátás és a rovatok hagyományos presztízse a meghatározó. Környezetvédelmi témájú cikket megjelentetni jelenleg nehéz: másodrangú belpolitikai témák is kiüthetik vagy csökkenthetik az erre szánt oldalszámot. (Meg lehet kérdezni bármely környezetvédelmi cikket publikáló újságírót. Ennél részletesebben a szerkesztőségek szkeptikus attitúdjéről a környezeti kérdésekkel kapcsolatban lásd Cselószki, 2000.) A nagy kiadóvállalatok gyakorlatában az utóbbi évtizedekben is inkább a marketing- és a reklámstratégia elôtérbe tolása jellemzô a példányszámnövelés érdekében, és csak második lépés a szerkesztőségi oldalak megváltozása.

A médiatartalmakkal kapcsolatban tennék még egy utolsó megjegyzést: a nagyobb publicitást kapott ökológiai események környezeti szempontból sokszor ártalmasak, míg reprezentációjuk hozzájárul az ökotudatosabb szemlélethez. A környezeti katasztrófák (japáni atombalesetek, tiszai cián-szennyezés) megnövelik a környezeti felelősség szintjét, a föleg $N I M B Y$ típusú környezetei konfliktusok rövid távon sokszor nagyobb környezetterhelést jelentenek, mint amit a tiltakozással megakadályozott tevékenység okozna, mivel azonban ezekben az ügyekben érvényes hivatkozási alapként jelenik meg a környezetei érdek, hosszú távon ennek érvényesülését segítik elô.

\section{FOGYASZTÁS ÉS IDENTITÁSGENERÁLÁS}

Sükösd Miklós második fontos állítása (a nem elégséges tájékoztatás felvázolása mellett) az, hogy a média egyrészt fogyasztást generál, másrészt nagy szerepet játszik az identitás és az attitưdök kialakításában, ám jelenleg a (kereskedelmi) média ez irányú tevékenysége az ökológiai fenntarthatóság szempontjából nem kedvező.

Az elsố és legfontosabb kifogás a kritikusok részéről, hogy nem helyes a lakosságot „eltorzított, mesterséges médiaélményt fogyasztó konzumidiótának” tekinteni (Z. Karvalics, p. 1.). Az észrevétel jogos, csak azzal nem számol, hogy konzumidióták márpedig vannak - csak a pejoratív felhangot és fogalomhasználatot érdemes lefordítani értelmes leíró kategóriákra, vagyis meg kell vizsgálni, hogy a lakosság mekkora hányada tartozik fogyasztásra orientált, magas szintû médiahasználatú életstílus-csoportokba, és azok milyen fogyasztói és választói erốt képviselnek. „A fiatalok egy része nem képes felvenni a többiekkel a versenyt. A mai fiatalok sokkal inkább széthúznak, mint valaha. Olyan társadalomban nőttek fel, amikor szinte egyik napról a másikra nyílt szét a társadalmi olló. Egyesek elszegényedtek, mások meggazdagodtak, de nem lázadnak, és nem is álmodoznak. Csak fogyasztanak. Ha álmodoznak is, legfeljebb arról, hogy még többet, még drágábbat, még könnyebben érjenek el.” Az idézet nem egy konzervatív értékrendet vagy morális pánikot megfogalmazó publicisztikából, és 
nem is a fogyasztói társadalmat ostorozó valamelyik zöld akcióujságból származik, hanem a GfK Piackutató Intézet által a magyar fiatalok életstílusáról készített tanulmány egyik markáns, empirikusan alátámasztott megállapítása (GfK, 2004, kiemelés tőlem).

De nézzük meg a részleteket. A mai magyar társadalmat az alábbi életstílus-csoportokba lehet besorolni:

\begin{tabular}{lc} 
Fogyaszt6i elit & $\mathbf{8 \%}$ \\
\hline Sikeres & $15 \%$ \\
\hline Élmény-gyđujtő & $\mathbf{1 0 \%}$ \\
\hline Hedonista beilleszkedett & $\mathbf{1 2 \%}$ \\
\hline Beilleszkedett mértékletes & $10 \%$ \\
\hline Megkapaszkodó & $\mathbf{1 7 \%}$ \\
\hline Lemaradó & $26 \%$ \\
\hline Nem besorolható & $2 \%$ \\
\hline
\end{tabular}

Forrás:TGI Magyarország 2003/1-4. negyedér. Kiemelés tôlem.

Fogyasztásra orientált, nem környezettudatos életstílus, a fogyasztói elit, az élménygyưjtő, a hedonista és a megkapaszkodó: a lakosság 47 százaléka, míg ennek fele az „ellenpont”, a tudatos fogyasztói magatartással rendelkezô csoportok, a sikeres és a mérsékletes: 25 százalék. Van egy harmadik csoport, a lakosság negyedét kitevố lemaradóké, akik nem azért nem fogyasztásorientáltak, mert nem akarnak azok lenni, hanem mert nem képesek erre. A magas szintû fogyasztásorientáltság pusztán a „jóléttôl”" nem jön létre, csak ha magas szintû́ médiahasználattal jár együtt.

A magas szintû́ fogyasztás-orientáltság, a márkafetisizmus és a nagy mértékú médiahasználat együttes előfordulása nem jelenti azt, hogy az előbbinek oka lenne az utóbbi, azaz lehet, hogy a fogyasztásnövekedésre más tényezốk hatnak, vagy a média hatása csak közvetett. A fogyasztást generálhatják strukturális okok és különféle mintakövetési gyakorlatok: a minta azonban nem feltétlenül a média, hanem lehet a vonatkozási csoport is. Sükösd feltevését gyengíti a TÁRKI felmérése a fogyasztási csoportokról: a kutatók úgy találták, hogy a legfontosabb mintát, a meghatározó erejứ vonatkoztatási csoportot elsôsorban a barátok és a közvetlen ismerősök jelentik - igaz, hogy a vizsgálatnak nem volt explicit módon megjelölt tárgya a médiatartalom (Fábián és tsai, 2000).

Sükösd kriktikusai joggal hívják fel a figyelmet arra, hogy a média közvetlen hatásának tézisét kikezdték az empirikus kutatások (Stuart Halltól Morley-n át Fiskéig), a médiatartalmak nem közvetlenül hatnak a befogadókra, akik aktívan értelmezik azokat. Fiske egyenesen értelmezési demokráciáról beszél. E kutatások során fốleg a kognitív jellegû́ tartalmakra kérdeztek rá, Sükösd azonban elsősorban nem az ilyen jellegû hatásokra utal, másrészt e kutatásokból nem következik, hogy a médiának ne lenne szerepe a hétköznapi világ megkonstruálásában. Először is, minden társadalmi intézménynek van társadalomkonstruáló szerepe: „Az újság az egyén számára valósága legszélesebb világát erősíti meg. Az idôjárás-jelentéstôl az apróhirdetésekig biztosítja arról, hogy ő valóban a legvalóságosabb világban él” (Berger - Luckmann, 1998:207). Másodszor, a média szocializációs közeg voltát eddig egyetlen kutatás sem 
kezdte ki (nem lehet tehát az iskolára és a családra mutogatni a média múködésmódjának megértése helyett). Harmadszor pedig, mint már utaltam rá, a média a környezet-képzetek és a kockázatok megkonstruálásának egyik fontos - ha nem is elsődleges - terepe.

Sükösd ráadásul nem is annyira a verbálisan megfogalmazható médiatartalmak racionális feldolgozásáról szól, legalábbis az én olvasatomban, hanem azokról a képzetekről, erősen beivódott képekről vagy imázsokról, amelyeknek észlelése sokszor a tudat alatt történik. Sükösd tézisét a médiának az identitásra gyakorolt hatásáról erôsítheti, ha a média-tartalmakat nem statisztikailag rubrikázzuk, hanem a használt nyelvezet szempontjából vizsgáljuk. Az uralkodó nyelv befolyásolja a valóság-konstrukciókat. Pierre Bourdieu habitusfogalmát idézve: a nyelv társadalmasítja a testet. Nem véletlen, hogy a már említett feminista, anti-rasszista mozgalmak akkora hangsúlyt fektetnek a politikailag korrekt beszédre. Egy nemrégiben közzétett nyelvészeti elemzés azt mutatta ki, hogy a „Jóbarátok” (Friends) címû népszerû televíziós mûsornak köszönhetően megváltozott a beszélt amerikai angol: a nyelv idomult a TV sorozathoz. (Nyelvújító jóbarátok, 2004)

A média mint intézmény része annak a viszonyrendszernek amit Michel Foucault a hatalom mikrofizikájának nevez: előállítója annak a diskurzusnak, elbeszélője azoknak az irányítási formáknak, amelyek irányítják, fegyelmezik a testet, a cselekvést és azt, ami elgondolható. A fenti felismeréseknek, a diskurzuselemzésnek és a feminista kritikának, továbbá a politikai ökológiának köszönhetően az uralkodó egyetlen „igaz diskurzus” (részben) feltöretett, a mainstream média azonban továbbra is többségi tényezőnek tekinthető. A „mert megérdemlem, mert megérdemled" (L’Oreal) diskurzust favorizálja, nem pedig a „Gondolkozz globálisan, cselekedj lokálisan” (zöld jelszó) diskurzusát, ami azért más szemléletet fejez ki.

Az ökológiai felelősség természetesen nem azt jelenti, hogy Milla Jovovich szépségében ne lehetne tovább gyönyörködni, hanem pusztán azt, hogy mint minden tevékenységnek, ennek is vannak környezeti költségei, amelyeket valakinek állnia kell. ${ }^{6}$ A környezeti javak szinte minden esetben kollektív javak. E kollektív javak fogyasztói látens nagycsoportot alkotnak (Olson, 1997), így a környezetei javak biztosítása kollektív szabályozókat igényel. Ilyen lehet például valamilyen adónem. A tapasztalatok szerint a kollektív szabályozók követése (például adómorál) szorosan összefügg azzal, hogy az érintettek köre tisztában van-e a szabályozók céljával (tudja-e, hogy mire megy a pénze). (Ezen nem is kell csodálkozni, lévén a modernitás legális-racionális uralmi rend.) Környezeti kérdésekben itt merül fel ismét a média szerepe. Ugyanúgy, ahogy nem mindegy, mi az uralkodó nyelvezet az adózás szempontjából (az „állami források” vagy az „adófizetôk pénze” alanyt használjuk valamely kontextusban), környezeti szempontból sem mindegy, hogy a „neked jár”, vagy a „vizsgáljuk meg felelősen, mi jut neked" szemlélete lesz-e domináns.

A dolgozat elején bemutatott környezetterhelési képlet szerint fontos elem a fogyasztás. A fogyasztást a világszemlélet és a fogyasztói attitûdök határozzák meg. Az 1993. évi Eurobarométer vizsgálat tanúsága szerint a „környezetvédelem és/vagy gazdasági fejlődés” kérdésében az EU országok válaszadóinak 69\%-a mondta azt, hogy dasági fejlődést biztosítani kell, de úgy, hogy egyidejűleg a környezet védelmére is figyelemmel kell lenni. Magyarországon ez az arány magasabb, 83\%. A magyar válaszadók 10\%-a azt mondta, hogy a környezet védelmének kell nagyobb prioritást adni, 
akár a gazdasági fejlődés rovására is. Ugyanakkor a környezet védeleméért a lakosság addig hajlandó áldozatokat hozni, amíg az nem jár az életszínvonal érzékelhetô csökkenésével.

A környezettudatos szemlélet és fogyasztási attitűdök kialakítása (a szemléletformálás) elengedhetetlen a környezeti válság megelőzése, illetve kezelése terén - az más kérdés, hogy ebben pontosan mekkora szerepe van a médiának, a jogi és anyagi szabályozóknak, a vonatkozási csoportoknak. Alapvető világnézeti váltás nélkül nem változik meg a környezetileg felelőtlen magatartás. Ez megint nem „újrafelhasználási szakmai" kérdés. Az utcai kutyaszar sem a Fökefe Ipari Kft. technológia kérdése. Lehet, hogy megoldható lenne a kérdés, ha jobb kiképzést és felszerelést kapnának az utcaseprôk és a GDP húsz százalékát erre fordítanánk, de a problémakezelés egyszerübb és hatékonyabb, ha a kutyatulajdonosok felveszik, ami az utcán marad kedvencük után. Az ilyen szemlélet kialakításában pedig lehet nagyon nagy szerepe a médiának, de elsôsorban nem minták nyújtásával, hanem a figyelemfelhívással. A ,valami búzlik Dániában" már nem érvényes kijelentés: a kutyaszarproblémát megoldották. Zöld szervezetek és nyugdíjas klubok kicsi dán nemzeti lobogókkal telitưzdelték azt, ami az utcán hevert, a média pedig ugyebár azokra a témákra utazik, amelyek az utcán hevernek. A feldíszített ürülék hatalmas médiabotrány keretében élő és premier plánban bemutatott látványát a nemzeti lobogóra nagyon büszke dánok nem tudták elviselni, s azóta nincs kutyaszar az utcákon.

Több szerző meggyőzően mutatott rá a média mozgósító szerepére (Alexander - Jacobs, 1998; Császi, 2002). A kritikai kultúrakutatás eredményeit részben megkérdőjelező vagy inkább más megvilágításba helyezô „neo-durkheimi” iskola arra hívja fel a figyelmet, hogy a média rituális közösségi élményt válthat ki, s ezáltal felerôsíthet társadalmi szolidaritási tevékenységeket. Az elmúlt két évtizedben a közvetlen részvétel és a formális tagság helyett újfajta civil tevékenységek figyelhetôk meg, melyek szervezésében és identitáskeresésében a mainstream média fontos szerepet játszik. Akár híradások, tudósítások is hozzájárulhatnak ehhez: egy-egy esemény közvetítése (például tömeggyưlés, adományozás, virágcsokrok vitele a Buckhingham Palace-hoz Lady Di halálakor) az eseményen való részvételre mozgósíthat. Bonyolultabb tehát a képlet annál, ami általában a zöld médiakritikában megjelenik, hogy az esemény után mindenki hazafut, hogy a TV híradóból merítsen valóságos élményt saját részvételéről az adott eseményen. Környezeti szempontból azonban nagyon nem mindegy, hogy a széles tömegek által fogyasztott média kupakgyưjtésre és technóra menetelő szemetelésre, vagy a tiszai árvíz által okozott károk elhárítására, illetve a szennyezés felszámolásra, az állatkínzás büntethetőségéért indított aláírásgyưjtésre (mint 2003/2004 telén történt), esetleg élelmiszerszállítmányok indítására mozgósít-e (mint ahogyan a romániai forradalom idején tette). Benyomásszerúen érzékelve úgy túnik, hogy egyre inkább az előbbi csoport dominál. 


\section{KÉT VILÁG}

Sükösd legkevésbé alátámasztott tézise a tapasstalati valóság, illetve a médiavalóság szembeállítása. A kritikusokkal egyetértve, nem lehet azt állítani, hogy a média által közvetített tartalom nem az értelemmel felruházott világ része: más a valóságkonstrukcióra gyakorolt hatása, mint a mákos tészta ízének, de ugyanannak a világnak a része. A részmegállapításokkal kapcsolatban is inkább a szkeptikus állítások tûnnek érvényesnek - ezeket az alábbiakban kiegészítem néhány (néha szubjektív) jelzéssel.

Az írott szó és a képi világ, a könyv és a TV szembeállítása nem tûnik megalapozottnak. Az olvasás semmivel sem kíván kevesebb kritikai hozzáállást, mint a vizuális kommunikáció: vannak, akik azt hiszik, hogy ha valami könyvben le van írva, az úgy is van; vannak, akik a filmet vagy akár a dokumentumfilmet hiszik valóságnak; és vannak, akik nem. Nyilván más-más készségeket kíván a különböző médiumok kezelése, e készségek azonban fejleszthetôk. Minél több tapasztalata és kifejlett készsége van egy adott médium használatában a befogadónak, annál kevésbé fogja azt nem médiumként, hanem valóságként kezelni.

A közvetlen tapasztalat és az ettôl eltávolított (magyarul: absztrakt) tudás szembeállítása is kétséges. A konszenzuális tudásban sokkal inkább érvényesíthetố a kommunikatív etika, a politikai ökológia egyik alapja (akár a feltételezett érdekeltek érveinek hangoztatásával), mint a tapasztalatiban („Nekem ne magyarázz, saját szememmel láttam!") A Lányi András nevével is fémjelzett Védegylet egyik kiemelt törekvése a jövő nemzedékek jogainak elismertetése. E kategóriánál absztraktabb fogalom kevés van, ugyanakkor e jogi fogalom hihetetlenül sokat segíthet a környezeti válság leküzdésben, illetve megelőzésében.

Ha visszakanyarodunk a médiához: a sérülékeny Föld látványa az ûrbốl, de akár a bánáti bazsarózsa misztikussá stilizált képe (lásd még a magyar nemzeti madár, a túzok képét) nagyban hozzájárulhat - „élőben” történő megtapasztalása nélkül is - a környezeti tudatosság kialakulásához. Itt, a Dob utcai lakók, az élőben megtapasztalt kocsik miatt kicsit bosszankodnak. Amennyiben végre nagyobb nyilvánosságot kapna az a Budapest térkép, amelyen a légszennyezés és a légúti daganatos megbetegedések elterjedése egymásra van vetítve, és a Dob utcaiak felülről nézve (mint akinek térkép e táj) szembesülnének azzal, hogy a magyarországi átlagos életkornál tíz évvel élnek kevesebbet a légszennyezés miatt, nem csak kicsit bosszankodva viszonyulnának a városi autózáshoz.

Ha Sükösd „médiatérben töltött” idejét lefordítjuk az intenzív médiahasználattal töltött idôre, a „másra nem jut idő” tézis akkor sem feltétlenül megalapozott. Logikusnak tûnhet, hogy annak, aki sokat használja az Internetet, kevesebb ideje jut az élổ kapcsolatokra. Csakhogy az internetezők jelentôs részének, sôt többségének sưrúbbek a társas kapcsolatai, mint a nem internetezóknek. E mögött egyrészt strukturális jellegú harmadik tényezők állnak (magasabb jövedelem, iskolázottság), másrészt az, hogy az Internet-használat nagyobb része esetükben éppen a társas kapcsolattartást szolgálja - e-mailen keresztül. Nem lehet szó nélkül hagyni azonban a digitális valóságkonstrukció esetleges kizárólagossá válását negligáló opponensi nézeteket sem: „a VR-rôl szóló elképzelések jelenlegi formájukban merő spekulációk" (Pintér, p. 7). Japánban mintegy 2,8 millió fốre teszik az otaku elnevezésû életstílus-csoport tagjainak számát, akik életüket teljesen a hálózati életre és a virtuális kapcsolatokra állítják be. 
A posztmodern kor egyik jellegzetessége a tér- és időszemlélet megváltozása: a turistáskodás térben és életútban egyaránt. A „bárhol” érzése nem feltétlenül jelent azonban környezeti felelő́tlenséget. Ez az új tapasztalati forma megtöltődhet a „bárhol, bármikor tehetek valamit az ökológia válság leküzdése érdekében" tartalommal: innen a Dob utcából is segíthetek a tasmán ördögök megmentésében Tasmániában. Nem állítom, hogy a bárhol-érzésben leledzốk többsége ilyen lenne, de a lehetôség adott.

Végezetül vitatkoznék azzal az implicit állítással, miszerint a TV-képernyô nézése önmagában károsabb a környezetre, mint sok egyéb szabadidős tevékenység. A médiafogyasztás egésze nem jár olyan nagy ökológiai lábnyommal. Az erőforrás-igényeket összesítve - a mûsorkészítéstôl a TV-készülékek előállításán és áramfogyasztásán át a szemészetig és a filmarchívumok vegyszerigényéig bezárólag - valószínűleg sok más bevett fogyasztói tevékenységénél kisebb ökológiai lábnyomot kapunk. Egy séta a kiépített ösvényư parkerdőben, vagy a beszélgetés a közeli Városliget valamelyik padján biztosan kisebb környezetterhelést jelent, egy franciaországi síelés azonban lehet, hogy felér egy évnyi televíziózással, míg a „shoppingolás a centerben” vagy a szkúterezés a Tisza-tavon már egészen bizonyosan. Néha lehet, hogy ökologikusabb, ha inkább bekapcsoljuk a tévét.

A valóság bonyolultabb annál, hogysem dichotóm kategóriákba gyömöszölhetnénk, még ha a modern ember világában gyakori is ez a fajta rendrakás.

\section{A STÍLUSRÓL}

Végezetül a stílusról. Úgy vélem, hogy ad hominem érvek a tudományban nem használhatók: egy tudományos érvényességre igényt tartó kijelentést annak igazságtartalma és nem annak közrebocsátója alapján kell megítélni. Ha a környezeti válságról csak tarisznyás Gaia-tudatú hard core rajongók tudósítanának (és nem lennének velük „egy táborban” világhíres tudósok), kijelentéseik akkor is érvényesek lennének, ha megfelelnek bizonyos érvényességi kritériumoknak. Annak megállapításához, hogy valami bûzlik, nem kell Nobel-díjasnak lenni, és nagyon bonyolult módszertani kritériumok sem szükségesek. Ehhez képest Sükösd Miklós kritikusai közül csak Dányi Endre nem használ ilyen érvet a vitában (az „agymerevedett zöldektôl” a csak sírni tudó „humánökológuson” át a „csak múvészekig”). „Talán nem járok túl messze a valóságtól, ha azt feltételezem, a recenzensek többsége nemhogy nem írta volna meg véleményét, de végig sem olvasta volna a dolgozatot, ha nem [Sükösd] Miklós küldi” - világít rá erre Hammer Ferenc. A legszomorúbb visszatérố gond ennek kapcsán a „hol az alternatíva?” kérdés a kritikusok részéről. A kérdéssel az a baj, hogy egyrészt egy erőteljes és összetett bűnbakképző előítélet része7, másrészt valójában tájékozatlanságot fed. A freonmentes hûtô egyik kifejlesztôje az „alternatívát nem kínáló” Greenpeace volt. A zöld kapitalizmusról és az alternatív gazdálkodási lehetőségekről szakkönyvek tucatjai szólnak (például egy klasszikus: Schumacher, 1991, és egy legfrissebb: Pataki - Takács-Sánta, 2004). A nemzetközi és Európai Uniós stratégiák és helyzetelemzések mellett a környezetvédő civil szervezetek rendszerint elkészítik állapotfelméréseiket és alternatíváikat, ezek közül a legismertebb a Jo'burg Memo. 
Magyarországon a HUMUSZ feltárta az összes, majd' kétezer illegáis szemétlerakót, s ezek egyharmadát felszámolta. (Az állami teljesítmény ugyanakkor 1, azaz egy ilyen lerakóhely megszüntetése.) A Levegő Munkacsoport minden évben elkészíti a zöld költségvetést. Az Energia Klub szinte minden évben publikálja alternatív, nemzeti energiastratégáját vagy annak bizonyos elemeit, miközben a Magyar Köztársaság kormánya 1993. óta képtelen volt ennek kidolgozására, pedig törvény kötelezi, hogy háromévente meg kell alkotnia... A fenntartható alternatívákkal nemcsak a zöld mozgalmak, hanem komoly tudományos múhelyek is foglalkoznak. Csak két kiadványsorozatra, nevezetesen a washingtoni Worldwatch Institute által „A világ helyzete” címmel évente megjelenô kötetekre és a BKÁE és az MTA „Zöld belépő” című sorozatára utalnék: Sükösd Miklós kritikusaitól ez a felszínesség és elfogultság számonkérhetô.

Ugyanakkor teljesen helytálló az az észrevételük, hogy a vitaindítónak felróható a túlzott általánosítás és a túl sötét jövő felfestése, valamint a már-már szépirodalmi stílus. A kritikusok viszont két rendkívül fontos dologról hallgatnak. A fennálló rendszert legitimáló, „optimista” mưveknek nem szokás felróni a tudományosság határát túllépő, nem elég árnyalt elemzést. Fukuyama máig a legtöbbször hivatkozott elemzők közé tartozik, a szociológia szégyenét jelentő „Bowling Alone” szociológiai közhellyé vált. A „nem elég tudományos” kitételben összefoglalható lesajnálás az ehhez hasonló vitákban általában a rendszerkritikus nézeteknek szól. Másrészt a Sükösd Miklóséhoz hasonló, túlhevített jelentések - a „Néma tavasz”-tól a Római Klub jelentésein át a „No Logo”-ig - nagyban hozzájárultak ahhoz, hogy a példaként emlegetett Düsseldorf vagy az Elba rehabilitációjára került forrás, létrejöhetnek és szigorodnak a környezetvédelmi szabályok.

Nem mellesleg: ki és honnan értesült arról, hogy az Elba-torkolat mintegy húsz éves, több millió márkát felemész tô, tavaly szabad fürdốzéssel megünnepelt újra élôvé tételét az idén egyetlen este teljesen tönkretette egy részeg hajóskapitány, akinek a hajója egy elavult, számos országban környezetszennyezố mivolta miatt betiltott bányászati eljáráshoz szállított vegyi anyagot?

\section{IRODALOM}

Alexander, Jeffrey C. - Jacobs, Ronald N. (1998): Mass Communication, ritual and civil society in Liebes, T. - Curran, J. (eds): Media, Ritual and Identity, London, Routledge

Beck, Ulrich (2003): A kockázat-társadalom, Századvég

Berger, Peter L. - Luckmann, Thomas (1998): A valóság társadalmi felépitése, Jószöveg Mühely, Budapest

Carson, Rachel (1995, 1962): Néma tavasz, Katalizátor Iroda, Budapest

Császi Lajos (2002): A média rítusai, Osiris - MTA, Budapest

Cselószki Tamás (2000): Környezetvédelem és média az ezredforduló Magyarországán, Médiakutató 2000/ôsz

Eder, Klaus (2000): A környezetvédelem intézményesülése: az ökológiai diskurzus és a nyilvánosság átalakulása in Szabó Márton - Kiss Balázs - Boda Zsolt (szerk.): Szövegváltozatok a politikára, Nemzeti Tankönyvkiadó, Universitas, Budapest 
ELTE Társadalomtudományi Szakkollégium (2004): Internet használó civil szervezetek kommunikációja két alsæektor tükrében, IHM kutatási beszámoló

\section{Eurobarométer (1993)}

Fact Intézet (1993): A városi lakosság viszonya a környezeti problémákhoz. Fact Intézet, Budapest

Fábián Zoltán - Kolosi Tamás - Róbert Péter (2000): Fogyaštási csoportok, TÁRKI, Budapest

Fidrich Róbert (2003): Zöldrefestés, MTVSZ

Füzesi Zsuzsanna - Tistyán László (1998): A környezeti tudat alakulásának elemzése a rendszerváltás óta eltelt időszakban, MTA Zöld Belépő 1998.

Gallup (1994): A Gallup International 1992-es és 1994-es nemzetközi vizsgálata a környezeti kérdésekről

GfK (2004): Fiatalok életstílusa és értékvilága, Hol a boldogság mostanában? - Stabil munkahelyen és jó családban, www.gfk.hu

Jakab Ferencné (szerk) (2004): Magyarország Környezetegészségügyi helyzete IV. Európai Környezet és Egészség Miniszteri Konferencia, Budapest, 2004, Fodor József Országos Közegészségügyi Központ Országos Környezetegészségügyi Intézete

Nyeloujitt jobarátok (2004): - http://www.sulinet.hu/tart/cikk/bn/0/18211/1

Pataki György - Takács-Sánta András (szerk) (2004): Természet és gazdaság, ökológiai gazdasági szöveggyiujtemény, Typotex, Budapest

Olson, Mancur (1997): A kollektív cselekvés logikája, Osiris, Budapest

Schumacher, Ernst F. (1991): A kicsi szép, Közgazdasági és Jogi Könyvkiadó, Budapest

Sükösd Miklós (2003) Totális medialitás és ökocídium in Információs Társadalom 2003/3-4

Szirmai Viktória (1999): A környezeti érdek Magyarországon, Pallas Stúdió 1999. TGI Életstílus, TGI Magyarorsæág 2003/1-4. negyedév.

Virágh Zoltán (2004): Védd a környezeted és az egészséged!, Magyar Orvosok az Egészséges Környezetért Társaság - Fodor József Országos Közegészségügyi Központ Országos Környezetegészségügyi Intézete

Vonnegut, Kurt (2004): Az ötös számú vágóhíd, Maecenas

Wackernagel, Mathis - Rees, William E. (2001, 1986): Ökológiai lábnyomunk, Föld Napja Alapítvány

Young, John E. (1994): Számítógépekkel a környezetért in Lester R. Brown (szerk): A világ helyzete, 1994, A Worldwatch Institute jelentése a fenntartható társadalomhoz vezetô folyamatról, Föld Napja Alapítvány 